\title{
Fermentation of seaweed flour with various fermentors to improve the quality of fish feed ingredients
}

\section{Fermentasi tepung rumput laut dengan berbagai fermentor untuk meningkatkan kualitas sebagai bahan baku pakan ikan}

\author{
Siti Aslamyah*, Muh. Yusri Karim, Badraeni \\ Program Studi Budidaya Perairan, Fakultas Ilmu Kelautan dan Perikanan \\ Universitas Hasanuddin, Jalan Perintis Kemerdekaan Km X, Tamalanrea, Makassar 90245 \\ *E-mail: siti_aslamyah_uh@yahoo.co.id/sitiaslamyah1@ @mail.com
}

\begin{abstract}
The purpose of this study was to evaluate various types of fermentor for dry matter digestibility (DMD), organic matter digestibility (OMD), and the chemical composition of fermented seaweed. Five types of seaweed were used as substrates included green strain of Kappaphycus alvarezii, brown strain of K. alvarezii, Gracilaria gigas, Sargassum sp., and Caulerpa sp. The treatments were four fermentors, namely Bacillus sp. $2 \mathrm{~mL} / 100 \mathrm{~g}$ of seaweed flour; $1.5 \%$ of tape yeast as a source of Rhizopus sp.; $1.5 \%$ of baker's yeast as a source of Saccharomyces sp.; a mix of Bacillus sp., tape yeast of Rhizopus sp. and baker's yeast of Saccharomyces sp. with compositions of $1 \mathrm{~mL}+1$ $\mathrm{g}+1 \mathrm{~g} / 100 \mathrm{~g}$ of seaweed flour; and control treatment. The results showed an increase in the percentage of DMD (21.94-27.76\%) and OMD (8.35-11.66\%) of all seaweed fermented using fermentor compared to control (DMD of $17.65-20.36 \%$ and OMD of 4.36-5.98\%). Moreover, the highest result was obtained by the fermentor mix (DMD of 24.86-27.76\% and OMD of 10.02-11.66\%). Similar result was also found in the chemical composition of fermented seaweed, there was increase in protein content of $9.23-15.93 \%$ and nitrogen free extract (NFE) of $56.05-70.26 \%$ in each seaweed treated with fermentation using fermentors, compared to controls (protein of 8.82-11.54\% and NFE of 52.26-65.72\%). Furthermore, the highest value was shown by seaweed fermented with mixed fermentors (protein of 9.92-15.93\% and NFE of 58.47-70.26\%). Yet, the opposite result was present in the ash, crude fiber, and fat content of seaweed fermented using fermentors of which the lowest value was found in treatment of mixed fermentor.
\end{abstract}

Keywords: fermentation, fermentor, seaweed, quality, feed ingredients

\begin{abstract}
ABSTRAK
Tujuan penelitian ini adalah mengevaluasi berbagai jenis fermentor terhadap kecernaan bahan kering (KBK), kecernaan bahan organik (KBO), dan komposisi kimia rumput laut terfermentasi. Lima jenis rumput laut digunakan sebagai substrat, yaitu Kappaphycus alvarezii strain hijau, K. alvarezii strain coklat, Gracillaria gigas, Sargasum sp., dan Caulerva sp. Perlakuan yang diuji empat fermentor, yaitu Bacillus sp. 2 mL/100 g tepung rumput laut; 1,5\% ragi tape sebagai sumber Rhizopus sp.; 1,5\% ragi roti sebagai sumber Saccharomyces sp.; campuran Bacillus sp., ragi tape Rhizopus sp., dan ragi roti Saccharomyces sp. dengan komposisi $1 \mathrm{~mL}+1 \mathrm{~g}+1 \mathrm{~g} / 100 \mathrm{~g}$ tepung rumput laut; serta kontrol. Hasil penelitian menunjukkan terjadi peningkatan persentase KBK $(21,94-27,76 \%)$ dan KBO $(8,35-11,66 \%)$ semua jenis rumput laut difermentasi dengan fermentor dibandingkan kontrol (KBK 17,65-20,36, dan KBO 4,36-5,98\%) dan yang tertinggi dengan fermentor campuran (KBK 24,86-27,76 dan KBO 10,02-11,66\%). Begitu juga yang terjadi pada komposisi kimia rumput laut difermentasi, terjadi peningkatan kadar protein $(9,23-15,93 \%)$ dan bahan ekstrak tanpa nitrogen/BETN $(56,05-70,26 \%)$ pada setiap rumput laut yang diberi perlakuan fermentasi menggunakan fermentor, dibandingkan kontrol (protein 8,82-11,54\% dan BETN 52,26-65,72\%), yang tertinggi ditunjukkan oleh rumput laut yang difermentasi dengan fermentor campuran (protein 9,92-15,93\% dan BETN 58,47-70,26\%). Namun, terjadi sebaliknya pada kadar abu, serat kasar, dan lemak rumput laut yang difermentasi dengan fermentor lebih rendah dibandingkan kontrol, dan terendah dengan perlakuan fermentor campuran.
\end{abstract}

Kata kunci: fermentasi, fermentor, rumput laut, kualitas, bahan pakan 


\section{INTRODUCTION}

One of fishery products that can be used as a source of carbohydrates and also functions as a binder in fish feed is seaweed. Seaweed is listed as the commodity mostly produced in Indonesia. The production reached $54.12 \%$ or 1.7 million tons of total aquaculture production in 2013 of which 630.7 thousand tons was from South Sulawesi (Ministry of Marine Affairs and Fisheries Republic of Indonesia, 2014). In term of chemical composition, seaweed generally consists of water $(27.8 \%)$, protein $(5.4 \%)$, carbohydrates $(33.3 \%)$, fat $(8.6 \%)$, crude fiber $(3 \%)$, and ash (22.25\%) (Alamsyah, 2013). Moreover, seaweed also contains enzyme, nucleic acid, amino acid, vitamin ( $\mathrm{A}, \mathrm{B}, \mathrm{C}, \mathrm{D}, \mathrm{E}$, and $\mathrm{K}$ ), and macro minerals such as nitrogen, calcium and selenium and trace minerals such as iron, magnesium, and sodium. The content of amino acid, vitamin, and mineral in seaweed is about 10 to 20 times higher if compared with land plants (Suparmi \& Sahri, 2009). Seaweed which has been widely known and used by human consists of three classes, namely type of red (Rhodophyceae), brown (Phaeophyceae) and green (Chlorophyceae). Seaweed is also distinguished by the content of colloids. Seaweed group producing agar or commonly known as agarofit is namely Gracilaria and Gelidium, while the group producing carrageenan or termed as karaginofit consists of Euchema and Kappaphycus. Other group called alginofit which is able to produce alginate includes Sargassum and Turbinaria.

However, seaweed is a plant-based material that has cell walls and crude fiber. As stated by Utomo et al. (2011), the main obstacle in the utilization of plant-based materials as raw material for fish feed is the high content of crude fiber and the presence of anti-nutritional substances and amino acid composition those are different from the raw materials of animal protein. Excessive concentration of seaweed in feed results in high level of fiber whereas fish have limitations in digesting fiber. Therefore, concerning the feed formulation, seaweed should be at an optimum concentration.

One effort to improve the digestibility of feed can be applied by fermenting seaweed, which will be used as raw material for feed, using biodegradator. Fermentation is a chemical process of organic substrate change in the presence of biochemical catalysts, those are enzymes produced by certain microbes, with the aim to simplify nutrient bond that is difficult to digest such as crude fiber which is found in fish feed ingredients. Seaweed fermentation can be conducted using microorganisms which function as biodegradator to improve the quality of feed ingredients. Utilization of Rhizopus sp. as fermentor to improve the quality of feed raw materials was reported by Amri (2007) in palm kernel meal and by Handajani (2011) in Azolla (aquatic plant) flour. Moreover, Amar et al. (2006) used Bacillus sp. to improve the quality of shrimp shells flour and Sukada et al. (2007) utilized Saccharomyces cerevisiae as fermentor in pollard, soybean bran, and cocoa shell. The purpose of this study was to evaluate the use of various fermentor types on dry matter digestibility (DMD), organic matter digestibility (OMD), and chemical composition of fermented seaweed.

\section{MATERIALS AND METHODS}

Materials used as substrates in fermentation process were five types of seaweed collected from seaweed farmers in Punaga Village, Takalar Regency. The five types of seaweed were $K$. alvarezii green strain, K. alvarezii brown strain, Gracilaria gigas, Sargassum sp., and Caulerpa sp. which had been cleaned and laid in the sun to dry. Furthermore, various types of seaweed were crushed and sieved up into flour.

Four treatments of fermentor were Bacillus sp. $2 \mathrm{~mL} / 100 \mathrm{~g}$ of seaweed flour; $1.5 \%$ of tape yeast as a source of Rhizopus sp.; $1.5 \%$ of baker's yeast as a source of Saccharomyces sp.; a mix of Bacillus sp., yeast of Rhizopus sp. and baker's yeast of Saccharomyces sp. with compositions of $1 \mathrm{~mL}+1 \mathrm{~g}+1 \mathrm{~g} / 100 \mathrm{~g}$ of seaweed flour; and control treatment. Three replications were performed for each treatment. Bacillus sp. used was the collection of the Laboratory of Nutrition and Food Technology, Faculty of Marine Sciences and Fisheries, Hasanuddin University with population density of $1.5 \times 10^{8} \mathrm{cfu} / \mathrm{mL}$, tape yeast contained $1.6 \times 10^{7} \mathrm{cfu} / \mathrm{g}$ of Rhizopus sp., and baker's yeast contained $1.2 \times 10^{8} \mathrm{cfu} / \mathrm{mL}$ of Saccharomyces $\mathrm{sp}$.

Fermentation was started by weighing each $100 \mathrm{~g}$ of seaweed flour which was later put in sealed plastic. Each $100 \mathrm{~g}$ of seaweed was treated by fermentor that has been dissolved in $20 \mathrm{~mL}$ of molasses and sprayed evenly using sprayer. Plastic wrapped the seaweed powder was sealed and the flour was incubated for 72 hours to give a chance to the fermentor to break the substrate apart. After 72 hours, the seaweed flour was 
steamed in boiling water for 1-2 min to inactivate the fermentor. Furthermore, analysis of several variables was performed.

The parameters measured were dry matter digestibility (DMD) and organic matter digestibility (OMD), as well as the chemical composition of the seaweed included protein, fat, ash, crude fiber, and NFE through the proximate analysis. Formula for the determination of dry matter and organic matter digestibility at in vitro are as follows:

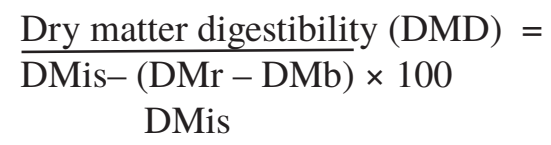

Organic matter digestibility $(\mathrm{OMD})=$

$\overline{\mathrm{OMis}-(\mathrm{OMr}-\mathrm{OMb})} \times 100$

OMis

Note:

$\mathrm{DM}=$ dry matter $(\%)$
$\mathrm{OM}=$ organic matter $(\%)$
is $\quad=$ initial sample
$\mathrm{r} \quad=$ residu
$\mathrm{b} \quad=$ blanco

All observation data obtained in this study were analyzed descriptively by comparing the results obtained among treatments and also by comparing it with the supporting literature.

\section{RESULTS AND DISCUSSION}

The percentage of DMD produced in this study ranged from 17.65 to $27.76 \%$ while the percentage of OMD ranged from 4.36 to $11.66 \%$ (Table 1). The lowest percentage value of DMD and OMD was produced by various seaweeds of control treatment (without fermentors) and followed by treatment of single fermentor. Moreover, mix treatment of Bacillus sp., Rhizopus sp., and Saccharomyces sp. resulted in the highest value.

The high digestibility in the treatment of seaweed fermentation using fermentor of mixed Bacillus sp., Rhizopus sp., and Saccharomyces sp. was presumably due to the contribution of different extracellular enzymes released by each microorganism. According to Chu (2007), Bacillus sp. is a microorganism producing alkaline extracellular protease enzyme with a maximum proteolytic activity of $2,560 \mathrm{U} / \mathrm{mL}$ at temperature of $50{ }^{\circ} \mathrm{C}$ for 48 hours under optimal conditions. Alkaline protease is an enzyme that hydrolyzes protein substrate in alkaline condition. Rhizopus sp. is a good producer of amylolytic enzyme, particularly glucoamylase (GA). This enzyme can lower both amylose and amylopectin by hydrolyzing $\alpha-1,4$ and $\alpha-1,6$ link of both glucoside starches and produce glucose (Nahar $e t$ al., 2008). Jaelani et al. (2014) reported that the contribution of microorganisms in a fermentation can reduce the concentration of neutral detergent soluble, acid detergent soluble, hemicellulose, and lignin, as well as increase the protein content. According to Okone et al. (2007), degradation activity of fiber components by microorganisms involved in the fermentation process occurs during ensilage. Moreover, bacteria will convert nonfiber carbohydrates into organic acids (acetate, lactate, propionate, and butyrate) during ensilage. Thus, the final product is more digestible than the material without fermentation.

Digestibility is the first indication of the availability of various nutrients contained in certain feed ingredients for fish to consume. High digestibility reflects the contribution of a particular nutrient, while feed having lower digestibility indicates that the feed is less capable in supplying nutrients for a basic living or for the purpose of fish production. Muhtarudin and Liman (2006) found that higher DMD means an increase in OMD and higher utilization possibility of nutrients for the production, vice versa.

This study resulted in percentage value of DMD and OMD which was relatively similar to the research result of Hardana et al. (2013) by fermenting cocoa shells using Aspergillus niger of which the value of DMD ranged from $18.6 \%$ to $25.1 \%$ and $O M D$ ranged from $3.4-13 \%$. However, the result of this study was lower than that of research conducted by Afrijon (2011) on cocoa shell without urea treatment (DMD of $46.37 \%$ ) and with 6\% urea-ammoniation treatment (DMD of $52.80 \%$ ) and was still much lower when compared to the research result of Yulistiani et al. (2012) which used different substrates, namely corn cobs treated with urea, Aspergillus niger and Aspergillus niger +0.5 urea which produced higher DMD of $59.7 \%$; $47.2 \%$; and $50.9 \%$, respectively. Tang et al. (2008) reported that OMD in feed supplemented with Saccharomyces cerevisiae reached a level of $56.8 \%$.

The level of organic matter digestibility is relatively higher than the digestibility of dry matter. This is because the dry ingredients still contain ash, while the organic matter does not contain ash; thus, material without ash content is 
Table 1. Percentage of dry matter digestibility (DMD) and organic matter digestibility (OMD) of seaweed with various fermentor treatments

\begin{tabular}{|c|c|c|}
\hline \multirow{2}{*}{ Treatment } & \multicolumn{2}{|c|}{ Parameter $(\%)$} \\
\hline & Dry matter digestibility (DMD) & Organic matter digestibility (OMD) \\
\hline КАН.K & $18.94 \pm 1.02$ & $5.98 \pm 0.88$ \\
\hline KAH.R & $25.69 \pm 0.82$ & $9.65 \pm 1.16$ \\
\hline KAH.S & $25.21 \pm 1.24$ & $9.25 \pm 1.35$ \\
\hline КАН.В & $22.69 \pm 1.35$ & $11.12 \pm 1.23$ \\
\hline KAH.C & $27.06 \pm 1.40$ & $11.54 \pm 1.30$ \\
\hline KAC.K & $19.85 \pm 1.16$ & $5.49 \pm 1.06$ \\
\hline KAC.R & $24.67 \pm 1.22$ & $9.71 \pm 1.32$ \\
\hline KAC.S & $25.36 \pm 1.37$ & $9.46 \pm 1.24$ \\
\hline KAC.B & $23.22 \pm 0.86$ & $11.57 \pm 1.24$ \\
\hline KAC.C & $26.87 \pm 0.62$ & $11.66 \pm 1.42$ \\
\hline GG.K & $18.93 \pm 1.22$ & $4.36 \pm 1.28$ \\
\hline GG.R & $25.43 \pm 1.15$ & $9.04 \pm 1.33$ \\
\hline GG.S & $25.78 \pm 1.32$ & $8.35 \pm 1.08$ \\
\hline GG.B & $21.94 \pm 1.27$ & $9.43 \pm 1.15$ \\
\hline GG.C & $27.76 \pm 1.04$ & $10.02 \pm 0.7$ \\
\hline SS.K & $20.36 \pm 1.08$ & $4.87 \pm 1.32$ \\
\hline SS.R & $26.35 \pm 1.30$ & $9.24 \pm 1.36$ \\
\hline SS.S & $25.34 \pm 1.26$ & $9.15 \pm 0.78$ \\
\hline SS.B & $24.36 \pm 1.14$ & $9.97 \pm 0.89$ \\
\hline SS.C & $27.00 \pm 1.18$ & $10.59 \pm 1.31$ \\
\hline CS.K & $17.65 \pm 1.35$ & $5.65 \pm 1.02$ \\
\hline CS.R & $23.58 \pm 1.15$ & $8.97 \pm 1.40$ \\
\hline CS.S & $23.14 \pm 1.40$ & $8.58 \pm 1.32$ \\
\hline CS.B & $22.25 \pm 1.27$ & $9.36 \pm 1.27$ \\
\hline CS.C & $24.86 \pm 1.23$ & $11.25 \pm 1.25$ \\
\hline
\end{tabular}

Note: $\mathrm{KAH}=$ Kappaphycus alvarezii green strain; $\mathrm{KAC}=$ K. alvarezii brown strain; $\mathrm{GG}=$ Gracilaria gigas $; \mathrm{SS}=$ Sargassum sp.; CS = Caulerpa $\mathrm{sp}$.; K = control; $\mathrm{R}=$ Rhizopus $\mathrm{sp}$.; $\mathrm{S}=$ Saccharomyces $\mathrm{sp}$.; $\mathrm{B}=$ Bacillus $\mathrm{sp}$.; $\mathrm{C}=$ mix.

relatively easier to digest. As proven by Fathul and Wajizah (2010), the addition of $\mathrm{Mn} 40 \mathrm{mg} / \mathrm{L}$ and $\mathrm{Cu} 10 \mathrm{mg} / \mathrm{L}$ can increase the ash content which later may slow or inhibit the digestibility of dry matter of feed ingredients. In addition, organic matter is composed of carbohydrates, proteins, fats, and vitamins. Since organic matter is a part of dry matter, increase in the dry matter will also increase organic matter, vice versa. A similar result will also apply to the digestibility value, that is an increase in dry matter digestibility leads to increase in organic matter digestibility.
Results of proximate analysis of seaweed fermented with various fermentors (Table 2) showed that there was increased level of protein and NFE in each seaweed treated with fermentation using fermentors, compared with control. Furthermore, the highest value was found in seaweed fermented with a mix of Bacillus sp., Rhizopus sp., and Saccharomyces sp. However, the content of ash, crude fiber, and fat in seaweed fermented with fermentors was lower than that of control, and the lowest result was obtained in the treatment of mixed fermentors. 
Table 2. Result of proximate analysis of seaweed by various fermentors

\begin{tabular}{|c|c|c|c|c|c|}
\hline \multirow{2}{*}{ Treatment } & \multicolumn{5}{|c|}{ Parameter $(\%)$} \\
\hline & Ash & Protein & Fat & Crude fiber & NFE \\
\hline КАН.K & $8.95 \pm 0.78$ & $11.54 \pm 1.27$ & $1.64 \pm 0.03$ & $15.73 \pm 1.18$ & $62.14 \pm 1.35$ \\
\hline KAH.R & $8.49 \pm 0.54$ & $13.13 \pm 1.05$ & $0.81 \pm 0.01$ & $11.37 \pm 1.04$ & $66.19 \pm 1.16$ \\
\hline KAH.S & $7.48 \pm 0.89$ & $13.37 \pm 1.12$ & $1.30 \pm 0.04$ & $11.70 \pm 1.13$ & $66.15 \pm 1.22$ \\
\hline КАН.В & $8.08 \pm 0.50$ & $14.06 \pm 1.34$ & $0.81 \pm 0.01$ & $11.06 \pm 1.26$ & $65.99 \pm 1.08$ \\
\hline КАH.C & $6.39 \pm 0.78$ & $15.93 \pm 1.21$ & $0.20 \pm 0.05$ & $11.23 \pm 1.24$ & $66.25 \pm 1.14$ \\
\hline KAC.K & $9.00 \pm 1.02$ & $11.27 \pm 1.4$ & $1.74 \pm 0.02$ & $14.90 \pm 1.35$ & $63.09 \pm 0.89$ \\
\hline KAC.R & $6.79 \pm 0.76$ & $14.32 \pm 1.22$ & $0.82 \pm 0.05$ & $11.56 \pm 0.89$ & $66.50 \pm 1.65$ \\
\hline KAC.S & $6.95 \pm 0.45$ & $14.31 \pm 1.35$ & $0.84 \pm 0.03$ & $11.39 \pm 1.33$ & $66.51 \pm 1.25$ \\
\hline KAC.B & $7.02 \pm 0.82$ & $14.21 \pm 1.3$ & $0.83 \pm 0.02$ & $11.26 \pm 1.14$ & $66.69 \pm 1.27$ \\
\hline KAC.C & $5.88 \pm 0.35$ & $15.27 \pm 1.27$ & $0.83 \pm 0.05$ & $10.73 \pm 1.12$ & $67.30 \pm 1.22$ \\
\hline GG.K & $10.14 \pm 0.98$ & $8.82 \pm 0.8$ & $0.91 \pm 0.01$ & $15.56 \pm 1.27$ & $64.58 \pm 1.14$ \\
\hline GG.R & $9.92 \pm 0.63$ & $9.61 \pm 1.05$ & $0.71 \pm 0.03$ & $11.04 \pm 1.06$ & $68.73 \pm 0.67$ \\
\hline GG.S & $10.97 \pm 0.75$ & $9.23 \pm 0.96$ & $0.29 \pm 0.01$ & $11.83 \pm 1.01$ & $67.67 \pm 1.27$ \\
\hline GG.B & $10.28 \pm 0.86$ & $9.42 \pm 1.27$ & $0.73 \pm 0.04$ & $12.47 \pm 0.85$ & $67.10 \pm 1.35$ \\
\hline GG.C & $9.48 \pm 0.78$ & $9.92 \pm 1.03$ & $0.82 \pm 0.04$ & $10.83 \pm 1.22$ & $68.95 \pm 1.16$ \\
\hline SS.K & $11.18 \pm 0.65$ & $10.88 \pm 1.09$ & $1.25 \pm 0.03$ & $10.97 \pm 1.08$ & $65.72 \pm 1.42$ \\
\hline SS.R & $9.07 \pm 0.45$ & $11.46 \pm 0.69$ & $1.00 \pm 0.02$ & $7.91 \pm 1.25$ & $70.55 \pm 0.76$ \\
\hline SS.S & $9.06 \pm 0.48$ & $12.95 \pm 1.07$ & $0.33 \pm 0.02$ & $9.37 \pm 1.07$ & $68.29 \pm 1.05$ \\
\hline SS.B & $9.66 \pm 0.94$ & $13.07 \pm 1.30$ & $0.85 \pm 0.03$ & $8.35 \pm 0.59$ & $68.07 \pm 1.20$ \\
\hline SS.C & $6.68 \pm 0.65$ & $13.55 \pm 1.23$ & $0.75 \pm 0.05$ & $8.76 \pm 1.27$ & $70.26 \pm 1.15$ \\
\hline CS.K & $13.19 \pm 1.4$ & $10.56 \pm 1.28$ & $1.91 \pm 0.03$ & $22.08 \pm 1.60$ & $52.26 \pm 1.27$ \\
\hline CS.R & $9.00 \pm 0.87$ & $11.04 \pm 1.04$ & $1.38 \pm 0.05$ & $20.53 \pm 1.02$ & $58.05 \pm 1.08$ \\
\hline CS.S & $7.22 \pm 0.99$ & $12.69 \pm 1.08$ & $1.22 \pm 0.05$ & $20.27 \pm 1.24$ & $58.60 \pm 1.13$ \\
\hline CS.B & $7.21 \pm 0.75$ & $12.82 \pm 0.88$ & $1.53 \pm 0.01$ & $20.20 \pm 1.07$ & $58.24 \pm 1.28$ \\
\hline CS.C & $7.29 \pm 0.68$ & $12.96 \pm 1.24$ & $1.31 \pm 0.03$ & $19.97 \pm 1.21$ & $58.47 \pm 0.92$ \\
\hline
\end{tabular}

Note: $\mathrm{KAH}=$ Kappaphycus alvarezii green strain; $\mathrm{KAC}=K$. alvarezii brown strain; GG = Gracilaria gigas; $\mathrm{SS}=$ Sargassum sp.; CS = Caulerpa $\mathrm{sp}$; $\mathrm{K}=$ control; $\mathrm{R}=$ Rhizopus sp.; $\mathrm{S}=$ Saccharomyces $\mathrm{sp}$; $\mathrm{B}=$ Bacillus $\mathrm{sp}$.; $\mathrm{C}=$ mix.

Increased level of protein and NFE of seaweed fermented with various fermentors was caused by enzymatic by fermentor and the addition of protein in fermentor cell. According to Sukaryana et al. (2011), work result of enzyme produced by microorganisms leads to changes in the fermentation process (either in aerobic or anaerobic condition). Akinfemi et al. (2009) showed that increase in crude protein content on fermentation of solid substrate occurs as a result of hydrolysis of starch into sugar when fungus degrades and dissolves the substrate which later will be used by the fungus as a source of carbohydrates to synthesize fungus biomass that is rich in protein. Further, fermentation of solid substrate on lignocellulosic feed ingredients using microorganisms can increase the protein content and lower the fiber content (cellulose and hemicellulose, neutral detergent soluble, acid detergent soluble). Jalil et al. (2015) reported that sago fermented with $R$. oligosporus could increase the reducing sugar by $61 \%$, glucose and fructose by more than $100 \%$, soluble protein by $1 \%$ and amino acids by $1.5 \%$ to $38.2 \%$.

It is known that crude fiber content in feed ingredients affect the digestibility or degradation 
of dry matter and organic matter. According to Suprapto et al. (2013), crude fiber content is not only able to affect the digestibility of dry and organic matter but also may affect the digestibility of other compounds. Rostika and Safitri (2012) stated that fermentation can improve the nutritional quality of feed ingredients through fiber degradation, fat degradation, and an increase in crude protein, which further will increase the digestibility of feed. Oduguwa et al. (2008) reported that fermentation with fungus $R$. oligosporus on rice bran and coffee hull increased NFE and lower fiber content. Mulia et al. (2015) also reported that tofu waste fermented with $\mathrm{R}$. oligosporus successfully decreased crude fiber content by $38-40 \%$.

A decrease in crude fiber was possibly caused by the breaking down of complex substances in the substrate into simpler compounds by fungus T. harzianum. An increase in protein was sourced from biomass of growing fungus which is also a single cell protein (SCP). Biomass of fungus contained in the fermented material can contribute as a source of protein and is also expected to enhance the immune response of fish and shrimp (Kang et al., 2010). Compared with the crude protein content of corn cobs without treatment $(4.33 \%)$, crude protein content in corn cobs biodegraded using fungus Pleurotus ostreatus and treated with the addition of urea increased twice (Hatta \& Sugiarto, 2015). It is also explained that crude protein increase in fermented young corn cob can also occur due to the growth and proliferation of fungi during fermentation. In general, all end products of fermentation usually contain simpler and easier compounds to digest than the original materials; thus, the nutritional value of the ingredients will increase. Various types of microorganisms have the ability to convert starch into proteins by the addition of inorganic nitrogen through fermentation.

\section{CONCLUSION}

Fermentation of seaweed Kappaphycus alvarezii green strain, K. alvarezii brown strain, Gracilaria gigas, Sargassum sp., and Caulerpa sp. using fermentors of Bacillus sp. $2 \mathrm{~mL} / 100 \mathrm{~g}$ of seaweed flour; $1.5 \%$ of ragi tape yeast as a source of Rhizopus sp.; $1.5 \%$ of baker's yeast as a source of Saccharomyces sp.; mixed fermentors (Bacillus sp., tape yeast of Rhizopus sp. and baker's yeast of Saccharomyces sp. with compositions of $1 \mathrm{~mL}+1$ $\mathrm{g}+1 \mathrm{~g} / 100 \mathrm{~g}$ of seaweed flour) could increase the percentage of dry matter digestibility (DMD) and organic matter digestibility (OMD), protein content, and nitrogen-free extract (NFE), as well as decrease the content of crude fiber, fat, and ash of seaweed. The best fermentor was the mix of Bacillus sp., tape yeast Rhizopus sp., and Baker's yeast Saccharomyces sp.

\section{ACKNOWLEDGEMENTS}

The author would like to thank the Directorate General of Higher Education for funding this research through the National Priorities Research Master Plan for the Acceleration and Expansion of Indonesian Economic Development 20112025 (Penelitian Prioritas Nasional Masterplan Percepatan dan Perluasan Pembangunan Ekonomi Indonesia, PENPRINAS MP3EI 2011-2025) of The Fiscal Year 2015.

\section{REFERENCES}

Afrijon. 2011. Influence of using urea in pod cacao amoniation for dry matter and organic digestibility by in vitro. Jurnal Embrio 4: 1-5.

Akinfemi A, Adu OA, Doherty F. 2009. Assessment of the nutritive value of fungi treated maize cob using in vitro gas production technique. Livestock Research for Rural Development 21: 188.

Alamsjah MA. 2013. Gracilaria sp. waste, Lactobacillus sp. and Chlorella sp. integration on intensive aquaculture with aquaponic system. Journal of Natural Sciences Research 3 (11): 66-77.

Amar B, Philip R, Bright Singh IS. 2006. Efficacy of fermented prawn shell waste as a feed ingredient for indian white prawn, Fenneropenaeus indicus. Aquaculture Nutrition 12: 433-442.

Amri M. 2007. Effect fermented palm kernel cage portion in feed of common carp Cyprinus carpio L. Jurnal Ilmu-Ilmu Pertanian Indonesia 9: 71-76.

Chu WH. 2007. Optimization of extracellular alkaline protease production from species of Bacillus. Journal of Industrial Microbiology and Biotechnology 34: 241-245.

Fathul F, Wajizah S. 2010. Additional micromineral $\mathrm{Mn}$ and $\mathrm{Cu}$ in ration to rumen biofermentation activities of sheep in vitro method. Jurnal IImu Ternak dan Veteriner 15: 9-15. 
Handajani H. 2011. Optimalisasi substitusi tepung Azolla terfermentasi pada pakan ikan untuk meningkatkan produktivitas ikan nila gift. Jurnal Teknik Industri 12: 177-181.

Hardana NE, Suparwi, Suhartati FM. 2013. Cocoa pods (Theobroma cacao L.) fermentation using "probiotik x" its effect on dry matter digestibilities (DMD) and organic matter digestibilities (OMD) in vitro. Jurnal Ilmiah Peternakan 1: 781-788.

Hatta U, Sugiarto. 2015. Produksi tepung tongkol jagung muda hasil biodegradasi kapang Pleurotus ostreatus dengan enzim pemecah serat dan implikasinya pada pakan ayam pedaging. Jurnal Ilmu-Ilmu Peternakan 25: $1-7$.

Jaelani A, Djaya S, Rostini T. 2014. Characteristics and nutrition silage duckweed (family Lemnacea) addition with different additives. International Journal of Biosciences 5: 144150.

Jalil AA, Abdullah N, Alimon AR, Abd-Aziz S. 2015. Nutrient enhancement of ground sago Metroxylon sagu Rottboll pith by solid state fermentation with Rhizopus oligosporus for poultry feed. Journal of Food Research 4: $1-15$.

Kang HY, Yang PY, Dominy WG, Lee CS. 2010. Bioprocessing papaya processing waste for potential aquaculture feed supplementeconomic and nutrient analysis with shrimp feeding trial. Bioresource Technology 101: 7973-7979.

Ministry of Marine Affairs and Fisheries Republic of Indonesia. 2014. Analisis data kelautan dan perikanan. Jakarta: Kementerian Kelautan dan Perikanan.

Muhtarudin, Liman. 2006. Determination of utilization level of organic mineral to improve rumen bioprocess of goat by in vitro method. Jurnal Ilmu-Ilmu Pertanian Indonesia 8: 132140.

Mulia DS, Yulyanti E, Maryanto H, Purbomartono C. 2015. Quality Improvement of tofu waste as the raw material of fish feed with fermentation of Rhizopus oligosporus. Sainteks 12: 10-20.

Nahar S, Hossain F, Feroza B, Halim MA. 2008. Production of glucoamylase by Rhizopus sp. in liquid culture. Pakistan Journal of Botany 40: 1693-1698.

Oduguwa OO, Edema MO, Ayeni AO. 2008. Physico-chemical and microbiological analyses of fermented corncob, rice bran and cowpea husk for use in composite rabbit feed. Bioresource Technology 99: 1816-1820.

Okone A, Yimamu A, Hanada M, Izumitta M, Zinong M, Okamoto M. 2007. Ensiling characteristic of daikon Raphna satimus by product and its potentials as an animal feed resource. Journal Animal. Feed Science and Technology 136: 248-264.

Rostika R, Safitri R. 2012. Influence of fish feed containing corn-cob was fermented by Trichoderma sp., Aspergillus sp., Rhizopus Oligosporus to the rate of growth of Java barb Puntius Gonionitus. APCBEE Procedia 2: $148-152$.

Sukada IK, Biduri IGNG, Warmadewi DA. 2007. The effect of fermented pollard, soybean hull, and cocoapod with "yeast culture" on carcass weight and meat cholesterol of male Bali duck. Majalah Ilmiah Peternakan 10: 1-10.

Sukaryana Y, Atmomarsono U, Yunianto VD, Supriyatna E. 2011. Improvement of crude protein and crude fiber digestibility of fermented product of palm kernel cake and rice bran mixture for broiler. Jurnal Ilmu Ternak dan Veteriner 1: 167-172.

Suparmi, Sahri A. 2009. Mengenal potensi rumput laut: Kajian pemanfaatan sumber daya rumput laut dari aspek industri dan kesehatan. Majalah Ilmiah Sultan Agung 44: 95-116.

Suprapto H, Suhartati FM, Widiyastuti T. 2013. Digestibility of crude fiber andcrude fat complete feed jute waste with different protein sources on post weaning etawa cross breed goat. Jurnal Ilmiah Peternakan 1: 938-946.

Tang SX, Tayo GO, Tan ZL, Sun ZH, Shen LX, Zhou CS, Xiao WJ, Ren GP, Han XF, Shen SB. 2008. Effects of yeast culture and fibrolytic enzyme supplementation on in vitro fermentation characteristics of low-quality cereal straws. Journal of Animal Science 86: 1164-1172.

Utomo NBP, Nurfadhilah, Ekasari J. 2011. Fermentation of Azolla sp. leaves and the utilization as a feed ingredient of tilapia Oreochromis sp. Jurnal Akuakultur Indonesia 10: 137-143.

Yulistiani D, Puastuti W, Wina E, Supriati. 2012. Effect of processing on nutritive value of corn cobs: chemical composition and in vitro digestibility. Jurnal Ilmu Ternak dan Veteriner 17: 59-66. 